\title{
The other's humanity with or without the other's religiosity? Reflections on the affirmation and limitation of human dignity in early Afrikaner missionary discourse in Central Africa
}

\begin{tabular}{|c|c|}
\hline \multicolumn{2}{|c|}{$\begin{array}{l}\text { Author: } \\
\text { Retief Müller }{ }^{1,2}\end{array}$} \\
\hline \multicolumn{2}{|c|}{$\begin{array}{l}\text { Affiliations: } \\
{ }^{1} \text { Nagel Institute for the Study } \\
\text { of World Christianity, Calvin } \\
\text { University, Grand Rapids, } \\
\text { Michigan, United States of } \\
\text { America }\end{array}$} \\
\hline \multicolumn{2}{|c|}{$\begin{array}{l}{ }^{2} \text { Department of Systematic } \\
\text { Theology and Ecclesiology, } \\
\text { Faculty of Theology, } \\
\text { Stellenbosch University, } \\
\text { Stellenbosch, South Africa }\end{array}$} \\
\hline \multicolumn{2}{|c|}{$\begin{array}{l}\text { Corresponding author: } \\
\text { Retief Müller, } \\
\text { rm38@calvin.edu }\end{array}$} \\
\hline \multicolumn{2}{|c|}{$\begin{array}{l}\text { Dates: } \\
\text { Received: } 30 \text { June } 2021 \\
\text { Accepted: } 10 \text { Aug. } 2021 \\
\text { Published: } 27 \text { Sept. } 2021\end{array}$} \\
\hline \multicolumn{2}{|c|}{$\begin{array}{l}\text { How to cite this article: } \\
\text { Müller, R., 2021, 'The other's } \\
\text { humanity with or without } \\
\text { the other's religiosity? } \\
\text { Reflections on the affirmation } \\
\text { and limitation of human } \\
\text { dignity in early Afrikaner } \\
\text { missionary discourse in } \\
\text { Central Africa', Verbum } \\
\text { et Ecclesia } 42(2) \text {, a2324. } \\
\text { https://doi.org/10.4102/ } \\
\text { ve.v42i2.2324 }\end{array}$} \\
\hline \multicolumn{2}{|c|}{$\begin{array}{l}\text { Copyright: } \\
\text { (C) 2021. The Authors. } \\
\text { Licensee: AOSIS. This work } \\
\text { is licensed under the } \\
\text { Creative Commons } \\
\text { Attribution License. }\end{array}$} \\
\hline \multicolumn{2}{|l|}{ Read online: } \\
\hline 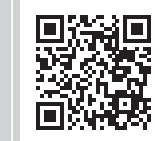 & $\begin{array}{l}\text { Scan this QR } \\
\text { code with your } \\
\text { smart phone or } \\
\text { mobile device } \\
\text { to read online. }\end{array}$ \\
\hline
\end{tabular}

Taking Wentzel van Huyssteen's work on early human uniqueness in relation to symbolic or religious awareness as a starting point, this article raises a question whether an implicit connection between humanity and the capacity for religiosity had anything to say about how one could evaluate the so-called other's religion and their humanity. Does the recognition of the other's full humanity demand an equal recognition of their religiosity, or are these separable? Rather than attempting to answer this hypothetically, the question is approached historically. The article touches on how the capacity to evaluate religion from the outside emerged in modernity and discusses some of the ways this capacity played out in Christian theology. In reference to the colonial era Afrikaner missionaries in Central Africa, the article argues that even partial recognition of the other's religiosity might have detrimental consequences particularly where this is tied to a partial recognition of their humanity as had happened during the apartheid and proto-apartheid periods.

Intradisciplinary and/or interdisciplinary implications: The article challenges both critical and affirmative scholarly views of religiosity by positing an essential link between humanity and religiosity whilst simultaneously suggesting that a scientific approach to religiosity, which has uncovered important relationships between religiosity and humanity, might be the appropriate approach for full recognition of the other's humanity.

Keywords: Afrikaner missionaries; colonialism; human dignity; Malawi; modernity; South Africa; theology.

\section{Introduction}

Wentzel van Huyssteen made profound contributions to the theological affirmation of human dignity through his research on the uniqueness of human origins (e.g. Van Huyssteen 2005, 2012). His more general gigantic impact on the academic discourse regarding science and religion is what comes to mind whenever his name is mentioned. Although this article will not seek to engage his oeuvre directly, the aim is to honour Van Huyssteen's legacy by showing connections to the central academic concern of religious awareness amongst early humans by placing it in a setting outside of Van Huyssteen's own scope of enquiry. Specifically, I will seek to connect and problematise aspects of Van Huyssteen's research interest to a theme that indirectly or directly relates to his background of rootedness in Africa.

Although I have always been an admirer of Van Huyssteen, I was never a student of his. I met and came to know him in Princeton in the early 2000s when I went there for my PhD studies, but my field of study was in history and ecumenics rather than in systematic theology. Despite our paths not really crossing in the academic arena, my wife and I were often beneficiaries of the famously warm Van Huyssteen hospitality during those years at Wentzel and Hester's Dickinson Street home.

One interesting thing about Van Huyssteen as a theologian is perhaps also something that makes him interesting as a human being. That is the fact that his career has been characterised by numerous challenges and transformations over time, not to mention personal tragedies and triumphs. One of his collaborators, Niels Henrik Gregersen, has done a service to interested readers by capturing many of the important foci especially in terms of the development of Van 
Huyssteen's ideas in the article, 'J. Wentzel van Huyssteen: Exploring Venues for an Interdisciplinary Theology' (Gregersen 2015). Whilst I do not intend to discuss these academic trajectories and their implications here, that has after all already been done by others who are much better qualified, it will suffice here to simply point out, as could perhaps be expected in any long and distinguished academic career, that Van Huyssteen's interests and research foci shifted over time. It seems that his interests evolved from an abstract, philosophical approach regarding the relationship between science and religion to an empirically based interest in palaeontology and early human 'cave art'. In other words, towards the latter part of his career his subject matter would increasingly be on themes that might also be of interest to anthropologists and archaeologists, for example.

In this article, I wish to relate to Van Huyssteen's later work in an analogical way via my own interests, in this case in reference to early Afrikaner missionaries in Central Africa. The case study presented below seeks to illustrate the relationship between views of religion and implications for human dignity, particularly views of the other's religion and the other's human dignity. Analogically, what will be discussed here, then, has relevance and provides historical commentary to Van Huyssteen's insight that religious awareness as seen in the use of symbolic language might perhaps be a primary distinguishing feature of early humanity (see Gregersen 2015:156-157). Yet, if the capacity for religion, or more generically symbolism, is inherently part of being human, then it leads me to consider another question, which is whether the appreciation of and respect for another's human religiosity is in fact closely tied to the appreciation for their human dignity. It seems a logical deduction that this should be answered affirmatively if one already posits, theologically, that human uniqueness has been indelibly tied to religious awareness from the outset. This is in any case an argument that will be proffered and somewhat problematised in this article.

The South African context out of which Van Huyssteen emerged was apartheid South Africa, of course, which was itself a continuation of and, if one could compare it to a virus, something of a mutant strain of colonialism in Africa, a 'colonialism of a special type' (see African National Congress 1980). As a form of systemic racism in overdrive, it denied vast numbers of people their full humanity, treating Africans as, essentially, children on a lower level of civilisation and development in comparison with the white so-called 'Europeans'. This notion underpinned much of the religiosity within the Dutch Reformed Church, the church in which Van Huyssteen was baptised and eventually ordained as a minister (see Gaum 2021). The systemic racism that would eventually lead to apartheid was particularly noticeable in the DRC missionary interactions with Africans and the policies growing out of such interactions (See Elphick 2012:222ff.). Van Huyssteen is well known for his anti-apartheid stance from early on, and it might be interesting to wonder about the extent to which his own research in terms of relating religiosity and humanity might have been partly driven by the compromised positionality regarding this theme as found in the religious culture in which he was first nurtured. This article will not seek to answer such a hypothetical question, but it will seek to bring to light some aspects of this problematic religious culture in Afrikaner missionary history. The main question that we consider here is about how the evaluations of the other's religion impact one's understanding of the other's humanity and vice versa.

\section{Human dignity and religious identity}

To put it differently, when speaking about the other's religion, an important sub-question tied to that would be the question of human dignity, and whether one thinks a person's dignity is tied up or in any way connected to their religious beliefs. Although this may seem like an innocuous idea on the surface, depending on the extent to which one wishes to affirm this, or not, it may well open up an ethical can of worms. This is not the place to engage in a theoretical discussion regarding the construction of 'religion' as a concept originating from and therefore perhaps only properly belonging to Western Christendom (see Dubuisson 2007). Despite the interesting research done on this topic, for purposes of expediency I simply use the word religion in the current commonsensical way in which most people understand the term. This is as generically indicating the reverent belief systems of people, irrespective of the specific contents thereof. When understood this way, one might make the general comment that religions tend to intricately tie themselves to identity. Perhaps this even occurs precisely because of a kind of primordial link between humanity and religious/symbolic awareness. Whatever the case, anyone who thinks that religious freedom is a human right certainly thereby implies that the prohibition and even inhibition to practise one's religion would be an affront to one's human dignity. If this is so, does it mean that the making of disparaging remarks about a religious belief system should be prohibited, because views expressed about a religion is really inseparable from the people adhering to the religion? In such a scenario, the disparaging remarks about a religion are also simultaneously derogatory of the believers and damaging to their human dignity. One does not have to search too far to realise that for many people a perceived affront to their religion is indeed an affront to their being. Every time the prophet Muhammad is lampooned in a European cartoon, uproar predictably ensues. Occasionally this uproar ends in violence and terrorism. Theologically, from the point of view of the insider, such a reaction might be defended based on the notion of blasphemy, but no doubt the psychological and emotional pain experienced by believers is the fuel that actually feeds the fire when seemingly disproportionate instances of retribution are called for and acted upon. It goes without saying that there is nothing peculiarly Moslem about such extreme reactions. For one thing, the vast majority of Moslems are obviously not violent extremists, and for another it is a fact of history that forms of religious extremism have shown up in all world religions in various times and places (see Gurski 2020). 
The post-Enlightenment West has for long tried to differentiate between the person and their religion. Religion was supposed to become a choice rather than being inherently part of a person's identity. Charles Taylor's notion of the modern buffered self, versus the porous selves of premodernity helps to explain part of what had occurred in a disenchanted context such as the modern West (see Taylor 2008). A growing differentiation between the self and what is beyond the self, including an active spirit world, occurred in tandem with scientific advances in the West. Contrary to former times when different perceived realities tended to be more enmeshed, the 'secular age' allowed for that which was out there to be essentially isolated, observed and studied without fear of harming the self in the process. The self became buffered and in the process freed itself from the capacity to be controlled by forces belonging to the side of this unseen world of magic and gods and spirits:

As a bounded self I can see the boundary as a buffer, such that the things beyond don't need to 'get to me', to use the contemporary expression .... This self can see itself as invulnerable, as master of the meanings of things for it. (Taylor 2008:n.p.)

That is in theory how things were supposed to work, anyway. In fact, many individuals who belonged and otherwise subscribed to such a 'modern' worldview found themselves still deeply enmeshed in the spirit world. In other words, it turns out that buffered selves occasionally and perhaps not so occasionally had cracks in them. This complex reality that combined porous and buffered selves was further exasperated (perhaps created?) by the post-Enlightenment European 'discovery' of the New World and the resultant era of colonialism. The rules regarding which religion and the spirit world were supposed to function in modern societies became thoroughly challenged by the encounters with societies that saw things very differently. This is a problematic interchange that continues to exist and still influences intercultural discourses to this day.

\section{Modern and Colonial Christian theological evaluations of religion}

Let us return to the main theme of religion and human dignity. One could posit any scenario where a person honestly disagrees with another's religious positioning. Such a hypothetical person could think, for example, that contrary to the other's own misguided beliefs such religious positioning might actually be detrimental to the human dignity of both the other as well as to the dignity of those they have contact with. How does one approach such a perceived problem from the perspective of Christianity as a worldwide faith, when World Christianity itself represents a pluralistic, interreligious, hybrid reality formed through centuries of interactions with indigenous religions worldwide?

In response to the Nazi heresy in Europe, some mid-twentieth century Continental theologians had an answer which more or less amounted to all religion is bad religion. Barth's Calvinderived idea of idolatry or unbelief was quite broad, even comprehensive in its apparent inclusion of all religion, because the religious possibility within humanity has been sacrificed on Calvary (see Barth 2005:235-236, 240). As a prisoner of the Nazis, Dietrich Bonhoeffer had first-hand experience of the deviancy and failure of religiosity as practised by the institutional church in Germany. When he was there as an inmate at Tegel prison, Bonhoeffer wrote to his friend Eberhard Bethge proposing what is sometimes translated as 'religionless Christianity', although Bethge himself preferred the translated term 'non-religious interpretation' as more accurately portraying Bonhoeffer's intent (see Bethge 1967:61, no. 1).

Whilst such an approach that generally suspected expressions of human religiosity as approximations of idolatry might have made sense under the threat of Nazi occupation of all of Europe alongside an alarming co-optation of Christian symbolism, a similarly antagonistic approach to religion, especially the other's religion, was much more difficult to sustain in colonial era interactions between Christians and adherents of African, Asian and other religions. This was an area layered in complexity even in spite of the obviously skewed power relations characterising the era, which generally demanded that the white man's ideas about all things including religion were certainly the correct ideas. However, missionary-indigenous interactions often created their own unexpected power dynamics at the local level. Therefore, although theoretically such a perspective insisting that all religion is suspect and potentially idolatrous, including one's own, might help justify a hypothetical missionary's inequivalent denunciation of the practices and rituals of those being evangelised, it could not be much of a selling point for the missionary message either. Such an approach would typically be far too paradoxical a position for a missionary to be in with the consequence that many missionaries instead attempted to maintain integrity in another way, that is by affirming the good in whatever religion they encountered.

\section{Missionary points of contact and creation from one blood}

Of course, the search for 'points of contact' (e.g. Stanley 2009:230) between Christianity and other religions was often driven by pragmatic considerations, rather than motivated by any real appreciation of the other's religion. Still, the search for points of contact usually involved in-depth study of the religion under question, which in turn often led to unanticipated missionary respect for the object of study. If such respect were to be forthcoming, might one expect a similar increase in the missionary's estimation of the people being evangelised? In other words, could it be that Van Huyssteen's insight about early humans and their unique propensity for religion or spirituality was an insight that on a more general level intuitively influenced diverse people's mutual appreciation for one another's humanity? Let me place that question as a preface in consideration of a specific historical case.

South Africa's Dutch Reformed Church had a peculiar missionary enterprise in southern, central and west Africa 
starting in the late 19th century through the mid-20th century (see Du Plessis 1924). In these places, Afrikaner missionaries were actively engaging Africans, learning their languages, translating scriptures, teaching, giving medical care and of course preaching often in self-sacrificial circumstances leading to numerous deaths amongst missionary families, most typically because of Malaria. Whilst this was going on, the Afrikaner people at large, back in South Africa, were busy constructing an ethnic nationalism that would eventually lead to apartheid. How did Afrikaner missionaries in the field respond to these trends or how were they part of the discourse, if at all? It would be nice to expect that missionaries who had purposefully placed themselves amongst native Africans and dedicated their lives to minister to them, would be critical of and free from apartheid ideology. Although I can make something of an argument to the effect that it was partly true that many if not all of these Afrikaner missionaries held much less racist notions than was the norm amongst their kinsfolk back home, it would also be my supposition that the Afrikaner missionaries tended to be more racist than, say, their Scots Presbyterian missionary colleagues in Nyasaland, for example. That is conjecture and a generalisation, of course, but there are specific historical cases that could be analysed to partly substantiate the claim. Under the assumption introduced above that views of the other's humanity, in other words Afrikaner missionaries' anthropology of Africans cannot be separated from and naturally indicates their views of the other's religion, I now proceed to consider the case of the Rev. A.C. Murray, the first missionary sent out from DRC circles to Central Africa in 1889. This was long before the rise of apartheid as an official policy, but I refer to some of his views that I will discuss shortly as proto-apartheid views.

It is easy to point out the faults in the missionary armoury with the benefit of hindsight. Afrikaner missionaries had plenty of blind spots, not least regarding their own racism and sexism. However, on at least one aspect, their views were more laudable and closer to our contemporary mores than many of their cultural peers as well as some current ideas within the African society in which they operated. This has to do with the belief that Murray et al. shared with other evangelical Protestants regarding the biblical theme of human creation out of one blood (cf. Samson 2001:115), which is an important theological justification for both mission and ecumenism. Murray discussed this theme in the context of the abovementioned 'points of contact'. The first point of contact was the belief in the unknown God that the Chewa people, who were the primary targets of missionary work in central Nyasaland, worshipped, according to Murray. Murray equated the belief in this unknown God with the apostle Paul's evaluation of the religion of the people of Athens. Murray had some interesting commentary on the details of Chewa religion. For example, generalising a bit he stated that the religion of the 'Bantu' consisted of the worship of spirits, that they believed in a supreme being above and beyond everything, who created the world. 'But with him they don't have anything to do, except when they are in need or difficulty. Is this not similarly the case with many white people?' [transl.] (Murray 1931:48-49). What is striking, and perhaps surprising given that this book by Murray was published in the 1930s, is first of all the implicit identification with white people as Christian and black people as heathen. But even more interesting is the missionary suggestion that in some cases at least white Christians and black heathens approach their God in similarly erroneous ways.

In the midst of mentioning some less laudable aspects about Chewa religion and custom such as past practices of killing and burying a chief's wives with him when he died, the practice of uncovering sorcery by the administration of poison from the bark of a certain tree, unnamed malpractices involving initiation rites and so on, Murray arrived at what was evidently seen as the most central element, that is sacrifices and prayers for rain. He gave a fairly detailed description, which I translate thus:

In the case of drought, then it is either Chauta or another great spirit, perhaps of a previous supreme chief, who is angry. Consequently, a sacrifice is made, and what we might call a great heathen prayer time is held. (Murray 1931:50)

Murray continued to describe the details of what would occur during such a gathering, and then he came to the really interesting part, which I translate at some length:

[The Chewa] claim that prior to the arrival of the missionaries [in Nyasaland], they would receive an answer to such a prayer time... Since the beginning of our work our evangelists tell us of more than one occasion where the heathen's prayers were not answered. The loyal old evangelist Lukas Jam, for example, tells us that he was once with a big chief in a time of drought, when they held such a prayer time, but to no avail. He then told the headman that Mulungu would no longer accept such sacrifices, because his Word had now arrived in their land, and he wants to be worshipped according to the Word. The headman then asked him if he would pray. His answer was that if they all would gather together then he would do so. Then a great meeting of all the surrounding villages were called, and Lukas told them of the true God, and of Elijah and his prayer on Carmel, and eventually he called upon them to humble themselves before God. He then prayed a serious and powerful prayer, and the Lord did, to the surprise of the heathens, give a prompt answer in the form of abundant rains. (Murray 1931:50-51)

There are a number of observations to be made in reference to this narrative, including regarding the missionary's apparent trust, not only in the power of Christian prayer but also we may note his tacit acknowledgement of the success of pre-Christian 'heathen' prayers and ceremonies. In other words, Chewa religion had been successful. Chewa prayers and ceremonies had worked. They only became dysfunctional after the introduction of the missionary era. The unspoken subtext is neither that the Christian religion is the only religious truth, nor that there are plural religious truths of comparable value, but that the Chewa had a religion that was truthful or rather successful in terms of what it had sought to achieve until it became faced with the higher truth of the Christian gospel, which rendered the formerly 
successful Chewa religion ineffective. Perhaps this would be to erroneously conflate success and truth, but if a religion is inherently instrumental as I think Chewa religion was to some extent, and which might have been also partially the case for the missionary Christianity of the DRC, then we have a very murky differentiating boundary between truth and success. To put it differently, the unspoken intimation seems to be that if prayer works, then that means it is part of a true religion. Whether this interpretation regarding instrumentality in missionary and indigenous religion is correct or not, the missionary clearly indicates Christianity as both truer and more successful than Chewa religion, although the latter is implicated as not entirely without merit either.

We may compare this perspective to another, early to midtwentieth century missionary to Nyasaland, Rev. J.A. Retief. Retief, in his autobiography made much of the successful conversion of a Chewa Rain Goddess, Chauwa and what this had meant for the success of the mission. It is interesting in and of itself that Retief referred to Chauwa as a 'goddess' even after her conversion to Christianity. He wrote:

The step taken by Chauwa gave courage to a whole number of men and women to break with the heathendom. For more than a year Chauwa had to attend the baptism class and on a certain Sunday she was solemnly baptized with a great number of elders at the great church at Mkhoma in the presence of a great crowd of chiefs and other people. That was the first time that a goddess, a rain goddess, was baptized in Mkhoma: probably the only one in Nyasaland. [transl.] (Retief 1951:219)

Elsewhere, on a more general discussion of Chewa religion, Retief also wrote quite explicitly that the indigenous religion should indeed be considered and named religion, and not superstition as some people would like to have it (Retief 1951:141).

This discussion about rainmakers, and the way in which missionaries often grudgingly respected them, or were even in some cases in awe of them, feeds into the rationale surrounding connecting points, which is an important theme coming to the fore as seen in the following point made by Murray (1931):

In the heathen religion the missionary finds many points of contact which he can connect to his message from God's Word. He must make use of those, and never, no matter how foolish it is, should he mock or slight their religion. The heathens are very sensitive about this, and such an attitude quickly closes their hearts to the words of the worker. (p. 51)

The second point of contact is this very issue of one blood. This, according to Murray, stands in contrast with the Chewa religion, which is less clear on the notion of a single creation as origin of all humanity. Murray described the Chewa religion prior to the direct and disrupting onset of colonialism in that region, a development that would change perceptions dramatically. At that earlier stage, the Chewa people had an intact belief system including a creation narrative, which detailed their origins as a people. However, this narrative only pertained to the Chewa. It did not reference outsiders. To translate Murray directly from the original Dutch: 'They do not however know from where the Azungu or white people emerged - they are likely spirits' (Murray 1897:179).

If Murray and other missionary sources understood the above situation correctly, then adherence to and advocacy of the one blood doctrine may well be mentioned as a positive contribution of the missionary enterprise in these areas. However, this is hardly all that could be said about the matter. A question remains regarding exactly how missionaries like A.C. Murray saw Africans, then, because as indicated above, they were not seen as equals. Murray (1897) clarifies this explicitly in a discussion of the missionary education efforts:

We are also very careful not to raise the natives beyond their class. When the native is taught that he is just as good as the white, and that he stands on equal footing with him, there arises grave problems.... He is yet a child, and should in many respects be treated as a child.... We do not believe that there is in the face of God any distinction between a white and a black skin. We reject in the strongest possible terms the expression 'Ham's descendants'.... But we repeat, the natives of central Africa are still children in comparison with us, and they cannot yet occupy the place of adults alongside us. How many generations would still be needed for this to occur, we cannot say. (p. 224)

In the above extract, we have a good exposition of Afrikaner Christian paternalism in respect to black Africans, a kind of paternalism that would subsequently become defined by the term Voogdyskap [Guardianship] (see Cronje 1948) and which would serve as a primary motivating factor in early apartheid apologetics. Basically, 'Guardianship' might be categorised as a pessimist's rendition of the already notorious White Man's Burden, à la Rudyard Kipling (1899), and subsequently a justifying discourse for colonialism including missionary work. Similar to the White Man's Burden, 'Guardianship' upheld the notion of the white people's tutelage over the people of colour but withheld the idea that the latter should or could be 'uplifted' much, or at least not in any foreseeable timeframe.

\section{Conclusion: Partial recognition and human dignity}

It seems evident that in the example of the early DRC mission, at least in the example of A.C. Murray referred to above, there was indeed a kind of partial recognition of the other's religion, and an even stronger affirmation of it as a religion in the case of J.A. Retief. However, the latter was an exception and even in this case Chewa religion was clearly understood as inferior to missionary Christianity. In any case, Eybers' (1942) book on 'superstitions and folk customs' in Nyasaland likely represented the more typical ways in which Nyasa religions were evaluated from the side of Afrikaner missionaries. That there was, generally speaking, very little in the way of full or unconditional recognition in the sense of accepting Chewa religion as an equally valid system when compared to Christianity is hardly surprising. The 
missionaries understood themselves primarily as evangelisers. They were not there to exchange ideas and have dialogue about the possibility of equally valid yet conceptually divergent truth claims. Yet, in the acceptance of power residing in the religious system to influence materiality, both tacitly with respect to the Chewa religion prior to the advent of Christianity and more explicitly in reference to missionary Christianity and in both cases in connection to the rain rituals/prayers, it seems evident that A.C. Murray, for example, was no unadulterated buffered self in the Taylorian sense of the term. The spirit world had real life consequences for missionaries like Murray.

Yet, and this would indeed be logical from the perspective of a porous self where personhood and the beyond is intermeshed, a view of the other's religiosity directly implicates the other's identity. The partial, or limited recognition of the other's religion then becomes analogous to the partial, or limited recognition of the other's humanity (cf. Vosloo 2016). A.C. Murray's answer to the question of whether the Chewa is human is undoubtedly yes, but this is not the end of the matter, because, as we saw, that humanity was a limited humanity, tantamount to a kind of perpetual childhood. Clearly, A.C. Murray did not at all see himself as an enemy of black people. Nor was he religiously intolerant or overly disrespectful. It was quite the contrary. Yet, I have no hesitation in describing him and the other DRC missionaries as proto-apartheid missionaries. For apartheid to occur and to continue for more than 40 years, it did not have to completely 'other' the racial other. A partial 'othering' did nicely for that, and in fact it might be argued that it was precisely the limitedness of the 'othering' that made such a system morally defensible, if always suspect of being flawed, from the inside.

A nagging question emerging through all of this, particularly, if we refer back to Taylor, to anyone not inclined to view the buffered identity as a positive development in the history of the secular, is whether a buffered self is perhaps not a prerequisite for the ability to not only attain full recognition of the other's religion but also full recognition of the other's humanity. To answer this question affirmatively does not imply that we have to accede to the total erasure of difference either between people or their belief systems. Neither is this akin to an oversimplified claim of all paths leading to the same proverbial Rome, different religions being different channels to the same Paradise/Heaven/Nirvana/Valhalla, whatever the case might be. To answer such a question affirmatively does not require a subscription to any kind of religious truth claim at all. As stated before, a buffered identity simply allows an individual to isolate religious phenomena, to enable you to study them from the outside, as it were, even if not completely objectively of course. In short, it allows for the scientific approach to all of life, including religion. However, if religious expression, or at least the capacity for religious expression, is inherently part of what it means to be human, then I think the above makes clear why a complete rejection of the validity of the other's religiosity might easily be construed as a rejection also of their humanity. The case study I presented makes it clear why a partial recognition of the other's religiosity is also unhelpful, in fact how it might have been tied, historically, to a similarly problematic partial recognition of the other's humanity. The only viable approach for people wishing to live in full recognition of each other's humanity, then, seems to be the full recognition of the other in humanity's religiosity. That is in turn an affirmation of one's recognition of their full humanity.

Yet, how does one approach such a religion if one fully recognises it as valid religion whilst still finding oneself unable to agree with its truth claims? The best possible answer simply seems to be that one should do this in full humility. Honest humility itself is, of course, one of the worthiest of all human traits and it is also a central virtue in all religions recognising a higher power. Might it even be said that a capacity for humility is a prerequisite for being religious and therefore human?

\section{Acknowledgements Competing interests}

The author declares that they have no financial or personal relationships that may have inappropriately influenced them in writing this article.

\section{Author's contributions}

R.M. is the sole author of this article.

\section{Ethical considerations}

This article followed all ethical standards for research without direct contact with human or animal subjects.

\section{Funding information}

This research received no specific grant from any funding agency in the public, commercial or not-for-profit sectors.

\section{Data availability}

Data sharing is not applicable to this article as no new data were created or analysed in this study.

\section{Disclaimer}

The views and opinions expressed in this article are those of the author and do not necessarily reflect the official policy or position of any affiliated agency of the author.

\section{References}

African National Congress, 1980, Apartheid South Africa: Colonialism of a special type African National Congress, London.

Barth, K., 2005, Der Römerbrief (Zweite Fassung 1922), 17th edn., Theologischer Verlag Zürich, Zürich.

Bethge, E., 1967, 'Bonhoeffer's Christology and his “Religionless Christianity"', Union Seminary Quarterly Review xxiii(1), 61-77.

Cronje, G., 1948, Voogdyskap en apartheid, J.L. Van Schaik, Pretoria. 
Dubuisson, D., 2007, The western construction of religion: Myths, knowledge, and ideology, Johns Hopkins University Press, Baltimore, MD.

Du Plessis, J., 1924, 'Een Eeuw van Zendingarbeid. Haar Ontstaan, de Ontwikkeling en de Bloei van ons Zendingwerk', De Koningsbode, Desember, pp. 13-17.

Elphick, R., 2012, The equality of believers: Protestant missionaries and the racial politics of South Africa, University of KwaZulu-Natal Press, Scottsville, VA.

Eybers, J.H., 1942, Volksgewoontes en bygelowe in Niassaland, C.S.V. Boekhandel, Stellenbosch.

Gaum, F.M., 2021, Van Huyssteen, Jacobus Wentzel Vrede (Wentzel), elektroniese Christelike Kernensiklopedie (eCKE), viewed 09 June 2021, from https://ecke. co.za/van-huyssteen-jacobus-wentzel-vrede-wentzel/.

Gregersen, N.H., 2015, 'J. Wentzel van Huyssteen: Exploring venues for an interdisciplinary theology', Theology Today 72(2), 141-159. https://doi. org/10.1177/0040573615581547

Gurski, P., 2020, When religion kills: How extremists justify violence through faith, Lynne Rienner, Boulder, CO.

Kipling, R., 1899, 'The white man's burden', McClure's Magazine, February, 1899, p. 12.

Murray, A.C., 1897, Nyasaland en mijne ondervindingen aldaar, HolandschAfrikaansche Uitgevers-Maatschappij, Amsterdam.
Murray, A.C., 1931, Ons Nyasa-akker: Geskiedenis van die Nyasa sending van die Nederd. Geref. Kerk in Suid-Afrika, Pro Ecclesia, Stellenbosch.

Retief, J.A., 1951, Ontdekkings in Midde-Afrika, C.S.V.-Boekhandel, Stellenbosch.

Samson, J., 2001, 'Ethnology and theology: Nineteenth-century mission dilemmas in the South Pacific', in B. Stanley (ed.), Christian missions and the enlightenment, pp. 99-122, Curzon Press, London.

Stanley, B., 2009, The world missionary conference, Edinburgh 1910, William B. Eerdmans Publishing Company, Grand Rapids, MI.

Taylor, C., 2008, Buffered and porous selves, The imminent frame: Secularism, religion and the public sphere, viewed 01 September 2021, from https://tif.ssrc org/2008/09/02/buffered-and-porous-selves/.

Van Huyssteen, J.W., 2005, 'Human origins and religious awareness', Studia Theologica 59(2), 104-128. https://doi.org/10.1080/00393380500339586

Van Huyssteen, J.W., 2012, Alone in the world?: Human uniqueness in science and theology, William B. Eerdmans, Grand Rapids, MI.

Vosloo, R., 2016, 'Between the prose of justice and the poetics of love? Reading Ricœur on mutual Recognition in the light of harmful strategies of "othering", Études Ricoeuriennes/Ricoeur Studies 6(2). https://doi.org/10.5195/ERRS.2015.309 